\title{
PROFIL DUKUNGAN SOSIAL-PSIKOLOGIS YANG DIBUTUHKAN DAN DIPEROLEH ORANGTUA DENGAN ANAK SAKIT KANKER (SURVEY DI KOMUNITAS KANTONG DORAEMON)
}

\author{
Windi Afifah 1 \\ Meithy Intan Rukia Luawo ${ }^{2}$
}

\begin{abstract}
Abstrak
Orangtua dengan anak sakit kanker membutuhkan dukungan sosial-psikologis untuk membantunya menghadapi kondisi yang ada. Dukungan sosial-psikologis adalah bantuan yang diterima oleh seseorang dari orang lain dalam bentuk dukungan emosional, bantuan instrumental, memberi informasi, penilaian diri dan interaksi yang mendukung agar dapat meningkatkan kualitas hidup seseorang. Tujuan penelitian ini untuk memperoleh gambaran mengenai dukungan sosialpsikologis yang dibutukan dan diperoleh orangtua dengan anak sakit kanker di komunitas kantong doraemon. Penelitian ini merupakan penelitian kuantitatif dengan metode survey. Populasi dalam penelitian ini adalah 20 partisipan yang memiliki anak sakit kanker di komunitas dengan menggunakan teknik sampling jenuh, yang berarti seluruh populasi digunakan. Pengumpulan data menggunakan instrumen angket sosial-psikologis yang dibutuhkan dan diperoleh. Temuan dari hasil penelitian ini adalah: (1) Dukungan sosial-psikologis yang dibutuhkan mendapatkan hasil pada tiga kategori, yaitu 45\% tinggi, 35\% sedang dan $20 \%$ rendah; (2) Dukungan sosial-psikologis yang diperoleh mendapatkan hasil pada tiga kategori, yaitu 25\% tinggi, 55\% sedang dan 20\% rendah; (3) Dari lima indikator dukungan sosial-psikologis yang dibutuhkan dan diperoleh, masingmasing mendapatkan nilai yang beragam karena adanya berbagai faktor. Bagi orangtua dengan dukungan sosial-psikologis yang dibutuhkan dan diperoleh termasuk kategori tinggi maka akan berfungsi dengan baik karena kesesuaian diantara keduanya. Namun bagi orangtua yang belum memperoleh dukungan sosial-psikologis sesuai dengan yang dibutuhkan, maka penyedia dukungan berperan penting untuk memenuhi dukungan sosial-psikologis tersebut.

Kata Kunci: Dukungan sosial-psikologis, orangtua dengan anak sakit kanker
\end{abstract}

\begin{abstract}
Parents of children with cancer need social-psychological support to help them deal with the existing conditions. Social-psychological support is assistance received by someone from others in the form of emotional support, instrumental support, information support, appraisal support and supportive interactions in order to improve one's quality of life. The purpose of this study was to obtain a picture of the social-psychological support that is needed and obtained by parents
\end{abstract}

\footnotetext{
${ }^{1}$ Universitas Negeri Jakarta, windyafifah05@gmail.com

${ }^{2}$ Universitas Negeri Jakarta, meithyrl@unj.ac.id
} 
of children with cancer in the Doraemon Pouch Community. This research is a quantitative research with survey method. The population in this study were 20 participants who had cancer children in the community using saturated sampling techniques, which means that the entire population was used. Data collection using social-psychological questionnaire instruments needed and obtained. The findings of this study are: (1) Social-psychological support needed gets results in three categories, namely 45\% high, 35\% moderate and 20\% low; (2) Socialpsychological support obtained get results in three categories, namely $25 \%$ high, $55 \%$ moderate and $20 \%$ low; (3) Of the five indicators of social-psychological support that are needed and obtained, each gets a variety of values due to various factors. To help with the social-psychological needs and is obtained according to the high category, it will be done well because of its suitability for all. However, for those who have not received the socio-psychological support in accordance with what is needed, the aid provider needs to provide social-psychological support.

Kata Kunci: Social-psychological support, parents of children with cancer

Kebutuhan merupakan segala sesuatu yang dibutuhkan manusia untuk mempertahankan hidup sehingga mencapai tingkat kesejahteraan dan kenyamanan. Setiap individu memiliki kebutuhan yang tidak sama pada setiap tingkatannya, begitu juga yang terjadi pada indvidu yang sudah menjadi orangtua. Selain memenuhi kebutuhan dirinya sendiri, orangtua juga berperan penting pada pemenuhan kebutuhan anak-anaknya.

Setiap kebutuhan harus terpenuhi, jika tidak terpenuhi maka manusia akan mengembangkan depresi, putus asa, jijik, keterasingan dan sinisme (Hidayat, 2011). Persoalan menjadi semakin sulit terjadi pada orangtua yang anaknya menderita sakit kanker. Ketika anak didiagnosis penyakit kanker, orangtua akan merasa terkejut, panik, stress, menyalahkan diri sendiri, kebingungan, sedih, dan malu (Kristiani dkk., 2008). Selain itu, mereka memiliki resiko lebih besar untuk mengalami gangguan kecemasan, depresi dan post traumatic stress (Hagedoorn dkk., 2011); kesulitan dalam mengelola tanggung jawab rumah tangga sehari-hari, kehidupan kerja, merawat anak yang sakit dan anggota keluarga lainnya (Mader, 2016). Berbagai kondisi yang dialami orangtua menunjukkan bahwa orangtua perlu melakukan penyesuaian hidup untuk diri sendiri, anak-anak dan keluarga , untuk itu orangtua membutuhkan dukungan sosial (Papaikonomou, 2007).

Kebutuhan dukungan sosial-psikologis merupakan suatu daya atau kekuatan yang berasal dari diri individu untuk memperoleh suatu energi positif dari orang lain yang mampu membantu individu tersebut menghadapi apa yang sedang dialaminya. Jika kebutuhan dukungan sosial-psikologis tidak terpenuhi dengan baik, pada level yang layak dan tetap berfungsi dalam peranannya, yang kemungkinan besar akan semakin tidak berfungsi bahkan membutuhkan bantuan professional yang lebih beragam (Papaikonomou, 2007).

Selanjutnya jika dukungan sosialpsikologis yang diperoleh orangtua telah maksimal, maka dapat memberikan keringanan masalah emosional, membantu lebih stabil dalam menghadapi masalah (Safitri dkk., 2017), membantu dalam melakukan coping stress (Febriana, 2018), membantu bertahan secara psikologis (Kristiani dkk., 2008), memiliki kesabaran tinggi dalam menghadapi kondisi anak (Fauzia \& Halimah, 2015) dan memiliki karakter love dan hope (Sa'adadiyah, 2015).

Dukungan sosial-psikologis dianggap penting, tetapi pada beberapa hasil 
penelitian dan studi pendahuluan di komunitas kantong doraemon menunjukkan orangtua dengan kondisi tersebut belum maksimalnya dukungan sosial-psikologis yang diperoleh. Melihat kondisi tersebut, peneliti tertarik membahas isu ini karena berkaitan dengan kompetensi advokasi konselor. Menurut ACA (American Counseling Association) ketika konselor mengetahui faktor-faktor eksternal yang bertindak sebagai penghambat perkembangan individu, konselor dapat memilih untuk merespons melalui advokasi (Lewis dkk., 2011). Terkait dengan pernyataan tersebut, maka penting bagi konselor mengetahui hambatan yang terjadi pada orangtua dengan anak sakit kanker di komunitas.

Berdasarkan penjelasan hal-hal di atas maka peneliti bermaksud melakukan penelitian survey mengenai profil dukungan sosial-psikologis yang dibutuhkan dan diperoleh orangtua anak dengan kanker.

\section{Dukungan Sosial-Psikologis}

Dukungan sosial-psikologis ialah bentuk bantuan perhatian, bantuan motivasi, informasi, interaksi positif dan materi dari anggota keluarga atau orang lain yang dapat meningkatkan kualitas hidup seseorang (Sherbourne dan Stewart, 1991). Selanjutnya menurut House (1981) dukungan sosial-psikologis adalah transaksi antarpribadi yang melibatkan kepedulian emosional, bantuan instrumental, informasi, dan penilaian (informasi yang relevan dengan evaluasi diri).

Dukungan sosial-psikologis yang dipaparkan oleh Sherbourne \& Stewart (1991) dan House (1981), sama-sama menitik beratkan pada tindakan memberi bantuan secara emosional, instrumental, dan informasi. Berdasarkan hal tersebut maka dapat disimpulkan dukungan sosialpsikologis adalah bantuan yang diterima oleh seseorang dari orang lain dalam bentuk dukungan emosional, bantuan instrumental, memberi informasi, penilaian diri (evaluasi diri) dan interaksi yang mendukung agar dapat meningkatkan kualitas hidup seseorang.

Menurut Sherbourne \& Stewart (1991) bentuk-bentuk dukungan sosial-psikologis terdiri dari :

\section{Dukungan Emosional}

Dapat diberikan melalui pengekspresian perasaan positif, memahami secara empati, dan dorongan pengekspresian perasaan. Dukungan ini melibatkan kepedulian, cinta dan empati.

2. Dukungan Instrumental

Dukungan instrumental disebut oleh banyak orang sebagai dukungan nyata. Dukungan dapat diberikan dengan cara memberi kebutuhan benda, pangan, sandang atau pinjaman uang yang berguna untuk pengobatan anak.

3. Dukungan Informasi

Dukungan informasi yaitu bimbingan atau umpan balik yang dapat memberikan solusi untuk masalah. Dukungan yang diberikan dapat berupa informasi tentang penyakit dan prosedur pengobatannya.

4. Dukungan Penilaian

Dukungan penilaian yang melibatkan informasi yang relevan dengan evaluasi diri, yang membantu seseorang dalam melakukan penilaian atas kemampuan dirinya sendiri.

5. Interaksi Sosial yang Mendukung

Interaksi sosial yang mendukung yaitu hubungan persahabatan yang ditandai dengan menghabiskan waktu bersama orang lain dalam kegiatan yang menyenangkan. Dukungan ini diberikan dengan cara menemani aktifitas rekreasi dan bersenang-senang, yang dapat memberikan ketenangan dan pemandangan baru bagi seseorang yang sedang mengalami stress.

Sumber dukungan sosial-psikologis yang paling awal pada umumnya adalah orangtua, ditambah dan akhirnya digantikan oleh teman, saudara, pasangan, anak-anak, dan berbagai orang yang memiliki hubungan yang lebih terbatas dan spesifik 
seperti atasan dan rekan kerja, guru spiritual, guru, dokter, perawat, dan konselor (House, 1981).

Sementara itu sumber-sumber dukungan sosial-psikologis menurut Lubis (2009) dikelompokkan menjadi :

1. Orang-orang sekitar individu yang termasuk kalangan non-profesional seperti: keluarga, orangtua, pasangan (suami atau istri), teman dekat, atau rekan. Hubungan dengan kalangan nonprofesional atau significant others merupakan hubungan yang menempati bagian terbesar dari kehidupan serang individu dan menjadi sumber dukungan yang sangat potensial.

2. Profesional, seperti psikolog, konselor, dokter, yang berguna untuk menganalisis secara klinis dan psikis.

3. Kelompok-kelompok dukungan sosialpsikologis (Sosial Support Groups) seperti pekerja sosial yang berada di LSM, tokoh agama, dan anggota komunitas tertentu yang selama ini tidak pernah dikenal oleh individu sebelumnya.

Banyaknya jenis-jenis dukungan sosialpsikologis yang dijelaskan diatas, ternyata dukungan yang berasal dari keluarga dapat memberikan efek yang sangat besar bagi fungsi psikologis individu. Sumber dukungan lain yang juga bermanfaat bagi individu, adalah kelompok-kelompok dukungan sosial-psikologis. Kelompok pendukung (support groups) merupakan suatu kelompok kecil yang melibatkan interaksi langsung dari para anggotanya, menekankan pada partisipasi individu yang hadir secara sukarela yang bertujuan untuk bersama-sama mendapatkan pemecahan masalah untuk menolong anggota-anggota kelompok dalam meghadapi masalah serta menyediakan dukungan emosi kepada anggotanya.

Selanjutnya dukungan sosial-psikologis yang tinggi dapat memberikan manfaat. Dukungan sosial-psikologis yang tinggi dapat memberikan dapat memberikan keringanan masalah emosional, membantu lebih stabil dalam menghadapi masalah (Safitri dkk., 2017), membantu dalam melakukan coping stress (Febriana, 2018), membantu bertahan secara psikologis (Kristiani dkk., 2008), memiliki kesabaran tinggi dalam menghadapi kondisi anak (Fauzia \& Halimah, 2015) dan memiliki karakter love dan hope (Sa'adadiyah, 2015). Orangtua yang memiliki karakter love akan mampu menunjukkan cinta pada anak dan orang lain, dan juga menerima cinta dari orang lain, sehingga akan menciptakan kehangatan dalam hidupnya. Sedangkan orang tua yang memiliki karakter hope akan senantiasa berpikir mengenai tujuan masa depannya disertai dengan rencana dan usaha untuk mencapai harapannya, sehingga dalam hal ini orang tua mempunyai harapan bahwa anaknya dapat sembuh dari penyakit kanker.

Menurut Myers dalam (Hobfoll, 1986) mengemukakan bahwa sedikitnya ada tiga faktor penting yang mendorong seseorang untuk memberikan dukungan sosialpsikologis, diantaranya:

1. Empati, yaitu turut merasakan kesusahan orang lain dengan tujuan mengantisipasi emosi dan motivasi tingkah laku untuk mengurangi kesusahan dan meningkatkan kesejahteraan orang lain.

2. Norma dan nilai sosial, yang berguna untuk membimbing individu untuk menjalankan kewajiban dalam kehidupan.

3. Pertukaran sosial, yaitu hubungan timbal balik perilaku sosial antara cinta, pelayanan, informasi. Keseimbangan dalam pertukaran akan menghasilkan kondisi hubungan interpersonal yang memuaskan. Pengalaman akan pertukaran secara timbal balik ini membuat individu lebih percaya bahwa orang lain akan menyediakan dukungan.

Selanjutnya menurut Sarason \& Pierce (1987) terdapat beberapa penyebab yang mungkin membuat penyedia dukungan tidak memberikan bantuan, yaitu : 
1. Penyedia dukungan telah mengevaluasi masalah dari calon penerima dukungan sebagai hal yang tidak mengancam.

2. Penyedia dukungan percaya bahwa akan ada orang lain yang akan memberikan bantuan.

3. Penyedia dukungan sedang mengalami kesulitan sehingga tidak dapat membantu.

\section{Orangtua dengan Anak Sakit Kanker}

Orangtua dengan anak sakit kanker adalah Ayah atau Ibu maupun keduanya (orangtua kandung) dalam ikatan perkawinan keluarga yang sah yang memiliki anak dengan didiagnosis penyakit kanker usia di bawah 18 tahun. Ketika anak didiagnosis penyakit kanker, kondisi orangtua akan merasa terkejut, panik, stress, menyalahkan diri sendiri, kebingungan, sedih, dan malu (Kristiani dkk., 2008). Selain itu, mereka memiliki resiko lebih besar untuk mengalami gangguan kecemasan, depresi dan post traumatic stress (Hagedoorn dkk., 2011); kesulitan dalam mengelola tanggung jawab rumah tangga sehari-hari, kehidupan kerja, merawat anak yang sakit dan anggota keluarga lainnya (Mader, 2016).

\section{Kompetensi Advokasi Konselor}

Menurut ACA (American Counseling Association) kompetensi advokasi konselor adalah kegiatan advokasi yang dilakukan konselor ketika mengetahui faktor-faktor eksternal menjadi penghambat perkembangan individu. Selanjutnya secara konseptual advokasi dalam konseling tidak hanya melibatkan intervensi perubahan sistem tetapi juga implementasi strategi pemberdayaan dalam konseling langsung dengan individu, keluarga, dan kelompok (Lewis dkk., 2011).

Menurut Myers, Sweeney, \& White (2002) konselor professional membutuhkan persiapan yang mencakup metode dan teknik advokasi untuk aksi sosial dan kemajuan profesi. Konselor harus memandang advokasi sebagai bagian integral dari peran mereka dan memperoleh keterampilan yang diperlukan untuk membuat kegiatan advokasi menjadi efektif. Berdasarkan hal tersebut maka pada masa pendidikan konselor, mereka harus mendapatkan mata kuliah yang dapat membantu mereka mengembangkan keterampilan advokasi yang dibutuhkan.

Selanjutnya menurut American Counseling Association (ACA), konselor yang memberikan layanan advokasi pada komunitas harus memiliki keterampilan sebagai berikut, serta peneliti juga mencoba mengaitkan dengan mata kuliah yang diterima selama pendidikan:

1. Identifikasi faktor lingkungan yang mempengaruhi perkembangan klien.

2. Beri tahu komunitas tentang keprihatinan umum terkait masalah yang ada.

3. Kembangkan aliansi dengan kelompokkelompok yang bekerja untuk perubahan.

4. Gunakan keterampilan mendengarkan yang efektif untuk mendapatkan pemahaman tentang tujuan kelompok.

5. Identifikasi kekuatan dan sumber daya yang dibawa oleh anggota kelompok untuk proses perubahan sistemik.

6. Komunikasikan pengakuan dan penghargaan untuk kekuatan dan sumber daya ini.

7. Identifikasi dan tawarkan keterampilan yang dapat dibawa oleh konselor ke kolaborasi.

Sejalan dengan tersebut, Fiedler dalam (Trusty, J., \& Brown, 2005) juga mengemukakan keterampilan yang diperlukan untuk membuat advokasi menjadi efektif yaitu:

1. Keterampilan komunikasi

2. Keterampilan kolaborasi

3. Keterampilan penilaian masalah

4. Keterampilan memecahkan masalah

5. Keahlian organisasi

6. Keterampilan perawatan diri 


\section{Komunitas Kantong Doraemon}

Komunitas kantong doraemon adalah komunitas yang mewadahi pendampingan sosial bagi para pasien kanker dan penyakit kronis lainnya pada anak yang berasal dari luar jabodetabek dan mendapatkan rujukan ke rumah sakit nasional di Jakarta. Pendampingan yang diberikan dalam bentuk dukungan moral, psikologis dan administrasi rumah sakit. Komunitas ini resmi berdiri 2 September 2018 yang didirikan oleh Kang Parman bekerja sama dengan mahasiswa psikologi UIN Syarif Hidayatullah dan mahasiswa UNJ.

Hal yang melatarbelakangi komunitas ini terbentuk yaitu ketika pendiri komunitas merasa banyaknya orang yang memiliki anak sakit kanker dan sakit kronis lainnya kurang mengetahui informasi pengobatan serta minimnya sosialisasi tentang pengadministrasian pengobatan di rumah sakit. Komunitas ini berfokus pada pendampingan sosial untuk menjawab dilema keluarga pasien agar mereka tidak menghentikan pengobatan anaknya hanya karena minimnya informasi tentang pengobatan di rumah sakit. Sebelum resmi menjadi komunitas, Kang Parman mulai mendampingi beberapa pasien saja. Setelah resmi berdiri, komunitas ini pun mulai aktif mencari pasien yang membutuhkan bantuan pendampingan sosial.

Tempat relawan biasa berkumpul di Rumah Singgah Sahabat yang terletak di Jln. Kenari RT.06 RW.04 No.249 Kel. Kenari, Kec. Senen, Jakarta Pusat, DKI Jakarta. Selain di rumah singgah, para relawan juga sering bertemu di Masjid AsSyifa dan Family Room RMHC yang ada di Rumah Sakit Cipto Mangunkusumo. Program-program yang ada dalam komunitas ini diantaranya:

\section{Pendampingan sosial}

Program pendampingan administrasi pengobatan di rumah sakit. Program ini juga bertujuan untuk memberikan dukunga moral dan psikologis terhadap keluarga dan orangtua pasien.

\section{Berbagi}

Program memberikan kebutuhan pasien yang tidak difasilitasi oleh BPJS. Program ini bertujuan untuk membantu meringankan biaya pengeluaran kelurga pasien selama perawatan.

3. Sedekah Bersama

Program untuk mengajak masyarakat umum peduli melalui kegiatan bersedekah. Kegiatan ini biasa dilakukan dengan membagikan nasi bungkus setiap hari jum'at untuk para pemulung yang ada di Jakarta

4. Rumah Singgah Sahabat

Program untuk memberikan tempat tinggal sementara yang nyaman bagi keluarga pasien diluar jabodetabek selama pengobatan di Rumah Sakit Nasional di Jakarta.

\section{Ambulance Gratis}

Program untuk membantu mobilitas pasien dari Rusing ke Rumah Sakit. Selain itu program ini juga untuk memberikan layanan pengantaran jenazah jika ada pasien yang didampingi komunitas meninggal dunia.

Dari berbagai program tersebut, dukungan sosial diberikan dengan cara memberikan pendampingan sosial saat perawatan di rumah sakit. Selain itu dalam menjalankan setiap program tersebut komunitas melibatkan pihak-pihak lain seperti masyarakat umum dan juga komunitas lain. Saat ini belum ada program yang secara khusus bertujuan untuk memberikan dukungan sosial bagi orangtua. Namun untuk terpenuhinya dukungan sosial bagi orangtua, para relawan telah memberikan dukungan moril berupa pendampingan, memberikan motivasi dan diskusi dengan mendatangkan orangtua yang anaknya telah sembuh dari kanker.

Saat ini terdapat beberapa pasien anak yang menderita sakit kronis, diantaranya sakit gangguan hati, jantung dan kelainan kelamin. Sedangkan pasien yang menderita sakit kanker terdapat 12 pasien anak. Jenis kanker yang diderita diantaranya leukimia, 
retinoblastoma, kanker hati, kanker otot dan kanker otak. Jumlah pasien anak yang didampingi komunitas pada setiap waktunya dapat berubah. Hal ini dikarenalan setiap bulannya terdapat pasien yang meninggal dunia, dan juga pasien yang bertambah untuk didampingi.

Selanjutnya, komunitas juga memiliki tujuan untuk dapat berfokus membantu keluarga dari pasien anak, yakni orangtua pasien. Hal-hal yang biasanya sering dikeluhkan orangtua kepada relawan yaitu biaya hidup selama perawatan anaknya, administrasi rumah sakit, informasi pengobatan, dan masalah keluarga. Hal-hal tersebut memberikan pengaruh pada kondisi psikis para orangtua. Orangtua menjadi terlihat sedih, menangis hingga stres.

Melihat kondisi orangtua yang seperti itu, para relawan komunitas selama ini mencoba memberikan dukungan moral, pendampingan administrasi di rumah sakit, dan juga memberikan dukungan psikologis. Dukungan psikologis yang diberikan dengan cara melakukan kegiatan-kegiatan yang menyenangkan untuk mendukung kesehatan psikologis orangtua. Biasanya relawan akan membuat kegiatan seperti jalan-jalan dan orangtua diajak untuk ikut serta dalam kegiatan amal.

Selain itu, komunitas juga berencana untuk memberikan layanan konseling. Layanan konseling dapat dilakukan oleh relawan komunitas yang berlatar belakang pendidikan bimbingan konseling dan juga psikologi. Namun, layanan konseling sendiri belum terealisasikan sampai saat ini. Hal tersebut dikarenakan masih belum fokusnya komunitas pada program-program yang mendukung kondisi psikologis orangtua tersebut. Saat ini relawan masih berfokus untuk memberikan pendampingan administrasi rumah sakit dan juga dukungan moral saja. Selain itu, di komunitas masih kekurangan tenaga professional untuk memberikan layanan psikologis bagi pasien anak ataupun orangtuanya.

\section{METODE PENELITIAN}

Penelitian ini merupakan penelitian kuantitatif dengan metode penerlitian survey. Menurut Arifin (2011) penelitian kuantitatif adalah penelitian yang digunakan untuk menjawab permasalahan melalui teknik pengukuran yang cermat terhadap variabel-variabel tertentu, sehingga menghasilkan simpulan-simpulan yang dapat digeneralisasikan, lepas dari konteks waktu dan situasi serta jenis data yang dikumpulkan terutama data kuantitatif. Metode penelitian survey penelitian dengan mengumpulkan informasi dari suatu sampel dengan menanyakannya melalui angket atau wawancara untuk menggambarkan berbagai aspek dari populasi (Arifin, 2011). Selanjutnya populasi dalam penelitian ini adalah 20 partisipan yang memiliki anak sakit kanker di komunitas dengan menggunakan teknik sampling jenuh, yang berarti seluruh populasi digunakan sebagai sampel penelitian.

\section{HASIL PENELITIAN}

Berdasarkan Grafik 1.1 (terlampir) hasil penelitian dukungan sosial-psikologis yang dibutuhkan dan diperoleh orangtua dengan anak sakit kanker di Komunitas kantong Doraemon sebagai berikut:

1. Dukungan sosial-psikologis yang dibutuhkan mendapatkan hasil pada tiga kategori, yaitu $45 \%$ tinggi, $35 \%$ sedang dan $20 \%$ rendah. Sedangkan dukungan sosial-psikologis yang diperoleh mendapatkan hasil 25\% tinggi, 55\% sedang dan $20 \%$ rendah.

2. Dari lima indikator dukungan sosialpsikologis yang dibutuhkan dan diperoleh, masing-masingnya mendapatkan nilai yang beragam karena adanya berbagai faktor.

3. Perolehan gambaran dukungan sosialpsikologis yang dibutuhkan dan diperoleh dari 20 orang responden mendapatkan hasil.:

a. Terdapat 1 responden yang masuk pada kategori dukungan sosial- 
psikologis yang dibutuhkan rendah, namun dukungan sosial-psikologis yang diperoleh tinggi.

b. Terdapat 2 responden yang masuk pada kategori dukungan sosialpsikologis yang dibutuhkan tinggi, namun dukungan sosial-psikologis yang diperoleh rendah.

c. Terdapat 4 responden yang masuk pada kategori dukungan sosialpsikologis yang dibutuhkan dan diperoleh tinggi.

d. Sebanyak 13 responden yang memiliki dukungan sosial-psikologis yang dibutuhkan dan diperoleh berada pada kondisi yang cukup seimbang. Hal ini berarti antara dukungan sosial-psikologis yang dibutuhkan dan diperoleh tidak berbeda secara signifikan.

Sebagaimana secara konsep, dukungan sosial-psikologis merupakan bentuk bantuan perhatian, motivasi, informasi, interaksi positif dan materi dari anggota keluarga atau orang lain yang dapat meningkatkan kualitas hidup seseorang (Sherbourne \& Stewart, 1991). Bagi orangtua dengan dukungan sosialpsikologis yang dibutuhkan dan diperoleh termasuk kategori tinggi maka akan berfungsi dengan baik karena kesesuaian diantara keduanya. Sejalan dengan pendapat tersebut, beberapa penelitian menunjukkan bahwa dukungan sosialpsikologis yang tinggi dapat memberikan keringanan masalah emosional, membantu lebih stabil dalam menghadapi masalah (Safitri dkk., 2017), membantu dalam melakukan coping stress (Febriana, 2018), membantu bertahan secara psikologis (Kristiani dkk., 2008), memiliki kesabaran tinggi dalam menghadapi kondisi anak (Fauzia \& Halimah, 2015) dan memiliki karakter love dan hope (Sa'adadiyah, 2015).

Selanjutnya hal yang menjadi permasalahan yaitu ketika dukungan sosialpsikologis yang diperoleh belum terpenuhi sesuai dengan yang dibutuhkan. Penelitian Papaikonomou (2007) yang menunjukkan jika kebutuhan dukungan sosial-psikologis tidak terpenuhi dengan baik, maka mereka (orangtua dari anak yang memiliki sakit kanker) tidak dapat memenuhi kebutuhan pada level yang layak dan tetap berfungsi dalam peranannya, yang kemungkinan besar akan semakin tidak berfungsi bahkan membutuhkan bantuan professional yang lebih beragam.

Dukungan sosial-psikologis yang tidak terpenuhi dengan baik dapat disebabkan oleh penyedia dukungan yang tidak memberikan dukungan secara optimal. Menurut Sarason \& Pierce (1987) penyebab penyedia tidak memberikan bantuan yaitu: (1) penyedia dukungan telah mengevaluasi masalah dari calon penerima dukungan sebagai hal yang tidak mengancam; (2) penyedia dukungan percaya bahwa akan ada orang lain yang akan memberikan bantuan; dan (3) penyedia dukungan sedang mengalami kesulitan sehingga tidak dapat membantu. Berdasarkan pernyataan tersebut, rasa empati dari orang yang menjadi penyedia/sumber dukungan berperan penting dalam pemenuhan kebutuhan dukungan sosial-psikologis responden. Hal ini didukung pernyataan Myers (dalam Hobfoll, 1986) yang mengatakan setidaknya ada tiga faktor penting yang mendorong seseorang untuk memberikan dukungan, yaitu empati, nilai sosial dan pertukaran sosial.

Menurut Lubis \& Hasnida (2009) penyedia/sumber dukungan terbagi menjadi tiga kelompok yaitu : (1) Orang-orang sekitar individu yang termasuk kalangan non-profesional; (2) Profesional; dan (3) Kelompok-kelompok dukungan. Penyedia dukungan yang termasuk dalam orangorang sekitar individu dari kalangan nonprofesional yaitu keluarga dan teman-teman dekat responden. Keluarga dan temanteman dekat adalah orang yang paling berperan dalam pemberian dukungan dukungan sosial-psikologis. Penelitian Kristiani (2008) menunjukkan orangtua yang memiliki anak sakit kanker akan merasa senang dan terhibur ketika keluarga dan teman-teman dekat tidak mengucilkan 
anaknya yang sakit dan memberi semangat untuk terus berjuang.

Selanjutnya, penyedia dukungan yang termasuk kelompok professional dan kelompok-kelompok dukungan memiliki kaitannya satu sama lain dalam penelitian ini. Konselor yang merupakan penyedia dukungan dari kelompok professional dapat bekerja sama dengan komunitas yang termasuk sebagai kelompok dukungan. Bentuk kerja sama diantara dua penyedia dukungan ini terkait pada kompetensi advokasi yang harus dimiliki konselor.

Menurut ACA (American Counseling Association) menyatakan ketika konselor mengetahui faktor-faktor eksternal yang bertindak sebagai penghambat perkembangan individu, konselor dapat memilih untuk merespons melalui advokasi. Kegiatan ini dapat dilakukan dengan membela hak klien untuk mendapatkan akses kesumber daya atau layanan yang dibutuhkan (Lewis dkk., 2011). Peran utama konselor dalam situasi ini adalah sebagai sekutu. Konselor dapat membantu komunitas dengan membuat keterampilan khusus seperti hubungan interpersonal, komunikasi, pelatihan, dan penelitian (Lewis et dkk, 2011). Berdasarkan pernyataan tersebut, berarti konselor dapat mejadi mediator antara komunitas dengan lembaga lain yang dapat membantu dukungan sosial-psikologis menjadi terpenuhi bagi orangtua dengan anak sakit kanker.

Dalam melakukan layanan advokasi, konselor juga harus memiliki berbagai keterampilan yang membuat advokasi berjalan efektif. Menurut ACA (dalam Lewis dkk., 2011) keterampilanketerampilan advokasi tersebut seperti: (1) Mengidentifikasi faktor lingkungan yang mempengaruhi perkembangan klien; (2) Mengkomunikasikan kepada komunitas tentang masalah yang ada; (3) Kembangkan aliansi dengan kelompok-kelompok yang bekerja untuk perubahan; (4) Keterampilan mendengarkan yang efektif; (5) Mengidentifikasi kekuatan dan sumber daya yang dibawa oleh anggota kelompok untuk proses perubahan; (6) Mengkomunikasikan pengakuan dan penghargaan untuk kekuatan dan sumber daya yang ada dalam kelompok; (7) Mengidentifikasi dan memberikan keterampilan yang dapat dibawa oleh konselor ke kolaborasi.

\section{KESIMPULAN}

Berdasarkan hasil penelitian "Profil Dukungan Sosial-Psikologis yang Dibutuhkan dan Diperoleh Orangtua dengan Anak Sakit Kanker di Komunitas Kantong Doraemon" yang telah dipaparkan sebelumnya, maka dapat disimpulkan bahwa (1) Dukungan sosial-psikologis yang dibutuhkan mendapatkan hasil pada tiga kategori, yaitu $45 \%$ tinggi, $35 \%$ sedang dan $20 \%$ rendah. Sedangkan dukungan sosialpsikologis yang diperoleh mendapatkan hasil $25 \%$ tinggi, 55\% sedang dan $20 \%$ rendah (2) Dari lima indikator dukungan sosial-psikologis yang dibutuhkan dan diperoleh, masing-masingnya mendapatkan nilai yang beragam karena adanya berbagai faktor (3) Bagi orangtua dengan dukungan sosial-psikologis yang dibutuhkan dan diperoleh termasuk kategori tinggi maka akan berfungsi dengan baik karena kesesuaian diantara keduanya. Namun bagi orangtua yang belum memperoleh dukungan sosial-psikologis sesuai dengan yang dibutuhkan, maka penyedia dukungan berperan penting untuk memenuhi dukungan sosial-psikologis tersebut. Selanjutnya saran bagi penelitian selanjutnya peneliti bisa melakukan penelitian yang berfokus pada bagaimana kompetensi advokasi konselor yang memberikan layanan di komunitas.

\section{DAFTAR PUSTAKA}

Arifin, Z. (2011). Penelitian Pendidikan Metode dan Paradigma Baru. PT. Remaja Rosdakarya.

Fauzia, T., \& Halimah, L. (2015). Hubungan dukungan sosial dengan kesabaran ibu yang memiliki anak penyandang leukimia di yayasan kasih anak kanker bandung (ykakb). Prosiding Psikologi, 130-136. 
Febriana, N. F. (2018). Dinamika Coping Stress pada Orangtua Anak Penderita Kanker Darah (Leukimia) di Ruang Bermain Sahabat Anak Kanker RSSA Kota Malang. Skripsi, 1-106.

Hagedoorn, M., Kreicbergs, U., \& Appel, C. (2011). Coping with cancer: The perspective of patients' relatives. Acta Oncologica, 50(2), 205-211. https://doi.org/10.3109/0284186X.201 0.536165

Hidayat, D. R. (2011). Teori dan Aplikasi : Psikologi Kepribadian dalam Konseling. Ghalia Indonesia.

Hobfoll, S. E. (1986). Stress, Social Support and Women: Tehe Series in Clinical and Community Psychology. Herpe \& Row.

House, J. S. (1981). Work Stress and Social Support. Addison Wesley Publishing Company.

Kristiani, L., Wirawan, H. E., Kusumarojo, R. C., \& Tehuteru, E. S. (2008). Gambaran Emosi Ibu dari Anak Penderita Kanker. In Indonesian Journal of Cancer (Vol. 2, hal. 6062).

Lewis, J. A., Lewis, M. D., Daniels, J. A., \& D’Andrea, M. J. (2011). A Multicultural -Social Justice Perspective. Brooks/Cole, Cengage Learning, 362.

Lubis, N. L. (2009). Dukungan Sosial pada Pasien Kanker Perlukah? (Medan). USU Press.

Mader, L. R. (2016). Employment Situation of Parents of Long Term Chilhood Cancer Survivors. PLOS One, 11(3), $1-19$.

https://doi.org/10.1371/journal.pone.0 151966

Myers, J. E., Sweeney, T. J., \& White, V. E. (2002). Practice \& theory. 80, 394402.

Papaikonomou, M. (2007). Childhood cancer: A parent's perspective on social support, with a case illustration. Journal of Child and Adolescent Mental Health, 19(1), 65-73. https://doi.org/10.2989/172805807094
86636

Sa'adadiyah, N. (2015). Hubungan antara Dukungan Sosial dengan Character Strength Orang Tua dari Anak Penderita Kanker di Rumah Conta Bandung. Prosiding Psikologi, 1(2), 198-203.

SAFITRI, Y., BINAHAYATI, B., \& TAFTAZANI, B. M. (2017). Dukungan Sosial Terhadap Orangtua Anak Penderita Kanker Di Yayasan Komunitas Taufan Jakarta Timur. Prosiding Penelitian dan Pengabdian kepada Masyarakat, 4(2), 246-251. https://doi.org/10.24198/jppm.v4i2.14 296

Sarason, B. R., Shearin, E. N., Pierce, G. R., \& Sarason, I. G. (1987). Interrelations of Social Support Measures: Theoretical and Practical Implications. Journal of Personality and Social Psychology, 52(4), 813832. https://doi.org/10.1037/00223514.52.4.813

Sherbourne, C. D., \& Stewart, A. L. (1991). The MOS social support survey. Social Science and Medicine, 32(6), 705-714.

https://doi.org/10.1016/02779536(91)90150-B

Trusty, J., \& Brown, D. (2005). Advocacy Competencies for Professional School Counselors. Professional School Counseling, 8(3), 259-265. 


\section{Lampiran}

Lampiran Grafik

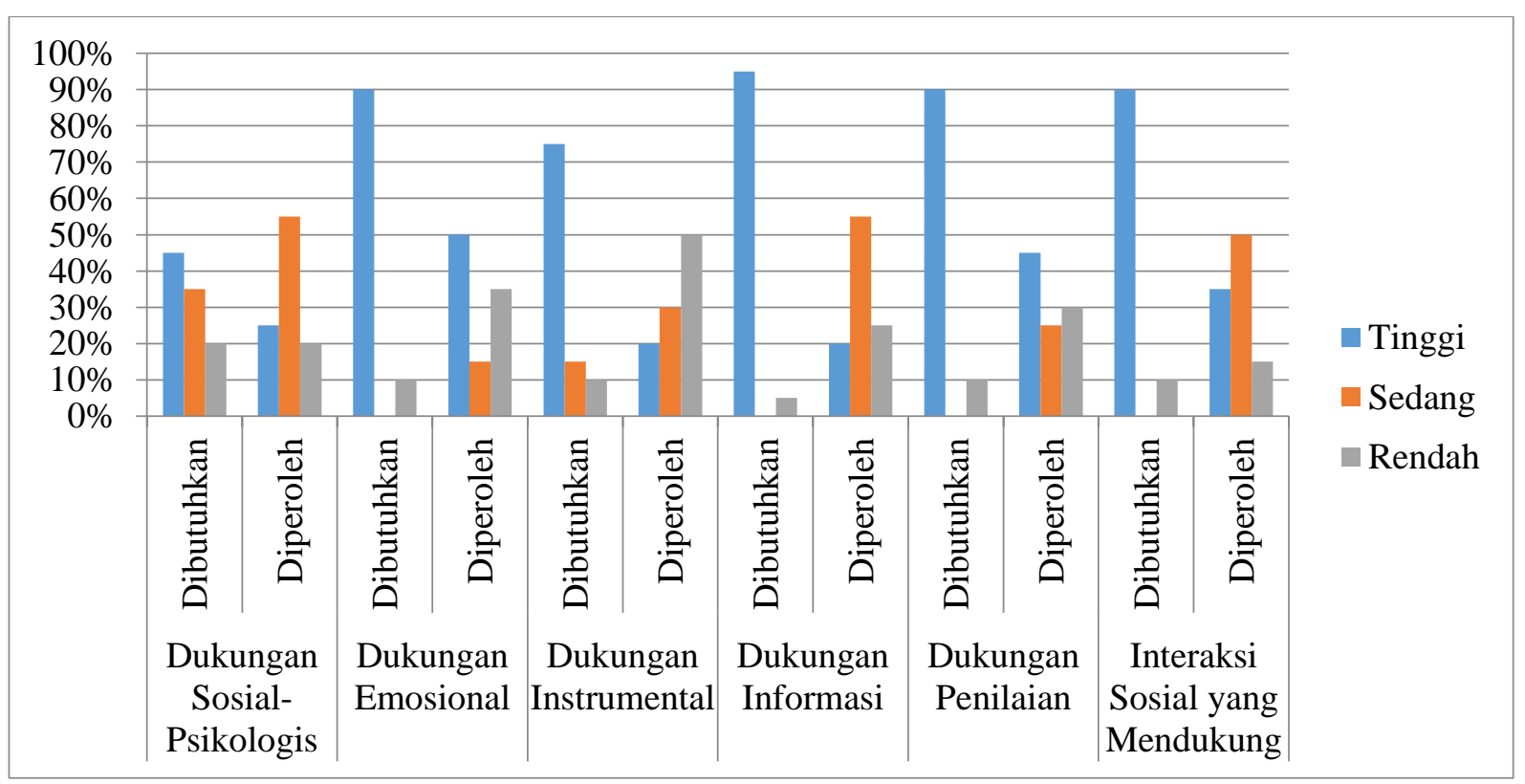

Grafik 1.1 Hasil Penelitian Dukungan Sosial-Psikologis yang Dibutuhkan dan Diperoleh 
Lampiran Instrumen

\section{Angket Dukungan Sosial yang Dibutuhkan}

Berilah tanda centang $(\sqrt{ })$ pada kolom jawaban yang sesuai dengan keadaan Bapak/Ibu rasakan saat ini!

\begin{tabular}{|c|c|c|}
\hline Pertanyaan & Ya & Tidak \\
\hline $\begin{array}{l}\text { 1. Saya membutuhkan orang-orang terdekat untuk berbagi suka dan } \\
\text { duka }\end{array}$ & & \\
\hline $\begin{array}{l}\text { 2. Saya membutuhkan penghargaan dan pengertian ketika bersama } \\
\text { dengan keluarga dan teman-teman dekat }\end{array}$ & & \\
\hline $\begin{array}{l}\text { 3. Saya membutuhkan keluarga sebagai pilihan pertama untuk } \\
\text { mencurahkan perasaan yang saya rasakan }\end{array}$ & & \\
\hline $\begin{array}{l}\text { 4. Saya ingin keluarga dan teman-teman dekat ikut memperhatikan } \\
\text { perkembangan kesehatan anak saya }\end{array}$ & & \\
\hline $\begin{array}{l}\text { 5. Saya membutuhkan dukungan ketika kondisi anak saya sedang } \\
\text { buruk }\end{array}$ & & \\
\hline $\begin{array}{l}\text { 6. Saya berharap keluarga ikut mendampingi anak saya ketika } \\
\text { menjalani pemeriksaan ke rumah sakit }\end{array}$ & & \\
\hline $\begin{array}{l}\text { 7. Saya ingin keluarga ikut membantu sebagian biaya perawatan atau } \\
\text { pengobatan anak saya }\end{array}$ & & \\
\hline $\begin{array}{l}\text { 8. Saya berharap orang-orang terdekat bersedia meminjamkan uang } \\
\text { untuk biaya perawatan anak saya ketika dibutuhkan }\end{array}$ & & \\
\hline $\begin{array}{l}\text { 9. Saya ingin orang-orang terdekat dapat diandalkan untuk } \\
\text { menggantikan saya menemani anak saya selama pengobatan }\end{array}$ & & \\
\hline $\begin{array}{l}\text { 10. Saya membutuhkan bantuan berupa makanan atau minuman untuk } \\
\text { saya ketika menjaga anak sewaktu pengobatan }\end{array}$ & & \\
\hline $\begin{array}{l}\text { 11. Saya membutuhkan informasi tentang pengobatan untuk anak saya } \\
\text { baik secara tradisional/modern }\end{array}$ & & \\
\hline $\begin{array}{l}\text { 12. Saya membutuhkan informasi tentang lembaga/komunitas yang } \\
\text { dapat membantu keperluan pengobatan anak saya }\end{array}$ & & \\
\hline $\begin{array}{l}\text { 13. Saya berharap ada orang yang dapat menjelaskan hal-hal yang } \\
\text { tidak saya mengerti tentang penyakit anak saya ini. }\end{array}$ & & \\
\hline $\begin{array}{l}\text { 14. Saya berharap orang terdekat dapat membantu mencari informasi } \\
\text { tentang prosedur pengobatan anak saya di rumah sakit }\end{array}$ & & \\
\hline $\begin{array}{l}\text { 15. Saya membutuhkan informasi tentang makanan/minuman yang } \\
\text { boleh dan tidak boleh dikonsumsi anak saya selama pengobatan }\end{array}$ & & \\
\hline $\begin{array}{l}\text { 16. Saya ingin keluarga melibatkan saya dalam pengambilan } \\
\text { keputusan mengenai pengobatan/perawatan yang akan anak saya } \\
\text { jalani }\end{array}$ & & \\
\hline $\begin{array}{l}\text { 17. Saya berharap orang lain menghargai usaha saya setiap kali selesai } \\
\text { mengatasi masalah pengobatan anak saya }\end{array}$ & & \\
\hline $\begin{array}{l}\text { 18. Saya berharap keluarga memberikan pendapatnya ketika saya akan } \\
\text { mengambil suatu keputusan pengobatan untuk anak saya }\end{array}$ & & \\
\hline 19. Saya ingin mendapatkan saran untuk pengobatan anak saya & & \\
\hline
\end{tabular}




\begin{tabular}{|c|c|c|}
\hline Pertanyaan & Ya & Tidak \\
\hline $\begin{array}{l}\text { 20. Saya membutuhkan saran pengobatan lain, ketika pengobatan yang } \\
\text { anak saya jalani tidak kunjung membuahkan hasil }\end{array}$ & & \\
\hline $\begin{array}{l}\text { 21. Saya merasa nyaman apabila bertemu dengan orangtua lain yang } \\
\text { anaknya sakit kanker sehingga dapat berbagi pengalaman }\end{array}$ & & \\
\hline $\begin{array}{l}\text { 22. Saya bersedia dilibatkan dalam kegiatan sosial di lingkungan } \\
\text { rumah }\end{array}$ & & \\
\hline 23. Saya senang bergaul dengan tetangga. & & \\
\hline 24. Saya membutuhkan kegiatan keagamaan bersama secara rutin & & \\
\hline $\begin{array}{l}\text { 25. Saya senang ketika masih bisa menggunakan media sosial untuk } \\
\text { berkomunikasi dengan orang lain }\end{array}$ & & \\
\hline
\end{tabular}

\section{Angket Dukungan Sosial yang Diperoleh}

Berilah tanda centang $(\sqrt{ })$ pada kolom jawaban yang sesuai dengan keadaan Bapak/Ibu rasakan saat ini!

\begin{tabular}{|c|c|c|c|c|}
\hline Pertanyaan & $\begin{array}{c}\text { Tidak } \\
\text { Pernah }\end{array}$ & Jarang & Sering & Selalu \\
\hline $\begin{array}{l}\text { 1. Keluarga dan teman dekat adalah tempat berbagi } \\
\text { suka dan duka saya }\end{array}$ & & & & \\
\hline $\begin{array}{l}\text { 2. Saya merasa dihargai dan dimengerti ketika } \\
\text { bersama dengan keluarga dan teman saya }\end{array}$ & & & & \\
\hline $\begin{array}{l}\text { 3. Keluarga bersedia menjadi tempat untuk } \\
\text { mencurahkan perasaan yang saya rasakan dan } \\
\text { memberikan solusi untuk menghadapi masalah } \\
\text { yang terjadi }\end{array}$ & & & & \\
\hline $\begin{array}{l}\text { 4. Orang-orang terdekat saya ikut memperhatikan } \\
\text { perkembangan kesehatan anak saya }\end{array}$ & & & & \\
\hline $\begin{array}{l}\text { 5. Orang-orang terdekat saya memberi penguatan } \\
\text { ketika kondisi anak saya sedang buruk }\end{array}$ & & & & \\
\hline $\begin{array}{l}\text { 6. Keluarga ikut mendampingi dan mengantar anak } \\
\text { saya ketika menjalani pemeriksaan ke rumah } \\
\text { sakit }\end{array}$ & & & & \\
\hline $\begin{array}{l}\text { 7. Keluarga saya membantu membayarkan } \\
\text { sebagian biaya pengobatan anak saya }\end{array}$ & & & & \\
\hline $\begin{array}{l}\text { 8. Orang-orag terdekat saya bersedia meminjamkan } \\
\text { uang untuk biaya perawatan anak saya }\end{array}$ & & & & \\
\hline $\begin{array}{l}\text { 9. Ada orang-orang yang dapat diandalkan untuk } \\
\text { menggantikan saya menemani anak saya selama } \\
\text { pengobatan }\end{array}$ & & & & \\
\hline $\begin{array}{l}\text { 10. Orang-orang terdekat saya memberikan bantuan } \\
\text { berupa makanan atau minuman untuk saya saat } \\
\text { menjaga anak saya }\end{array}$ & & & & \\
\hline
\end{tabular}




\begin{tabular}{|c|c|c|c|c|}
\hline Pertanyaan & $\begin{array}{c}\text { Tidak } \\
\text { Pernah }\end{array}$ & Jarang & Sering & Selalu \\
\hline $\begin{array}{l}\text { 11. Keluarga dan teman-teman saya berusaha untuk } \\
\text { mencari informasi tentang pengobatan untuk } \\
\text { anak saya baik secara tradisional/modern }\end{array}$ & & & & \\
\hline $\begin{array}{l}\text { 12. Keluarga dan teman-teman memberikan } \\
\text { informasi tentang lembaga/komunitas yang dapat } \\
\text { membantu keperluan pengobatan anak saya }\end{array}$ & & & & \\
\hline $\begin{array}{l}\text { 13. Keluarga dan teman-teman menjelaskan hal-hal } \\
\text { yang tidak saya mengerti tentang penyakit anak } \\
\text { saya ini. }\end{array}$ & & & & \\
\hline $\begin{array}{l}\text { 14. Orang-orang terdekat saya membantu mencari } \\
\text { informasi tentang prosedur pengobatan anak } \\
\text { saya di rumah sakit }\end{array}$ & & & & \\
\hline $\begin{array}{l}\text { 15. Keluarga dan teman-teman memberi informasi } \\
\text { tentang makanan/minuman yang boleh dan tidak } \\
\text { boleh dikonsumsi anak saya selama pengobatan }\end{array}$ & & & & \\
\hline $\begin{array}{l}\text { 16. Keluarga melibatkan saya dalam pengambilan } \\
\text { keputusan mengenai pengobatan/perawatan yang } \\
\text { akan anak saya jalani }\end{array}$ & & & & \\
\hline $\begin{array}{l}\text { 17. Saya merasa orang lain menghargai usaha saya } \\
\text { setiap kali selesai mengatasi masalah pengobatan } \\
\text { anak saya }\end{array}$ & & & & \\
\hline $\begin{array}{l}\text { 18. Keluarga memberikan pendapatnya ketika saya } \\
\text { akan mengambil suatu keputusan pengobatan } \\
\text { untuk anak saya }\end{array}$ & & & & \\
\hline $\begin{array}{l}\text { 19. Keluarga dan teman-teman memberikan } \\
\text { saran/nasehat untuk pengobatan anak saya }\end{array}$ & & & & \\
\hline $\begin{array}{l}\text { 20. Keluarga dan teman-teman memberikan saran } \\
\text { pengobatan lain, ketika pengobatan yang anak } \\
\text { saya jalani tidak kunjung membuahkan hasil }\end{array}$ & & & & \\
\hline $\begin{array}{l}\text { 21. Saya berkesempatan bertemu dengan orangtua } \\
\text { lain yang anaknya sakit kanker juga sehingga } \\
\text { dapat berbagi pengalaman }\end{array}$ & & & & \\
\hline $\begin{array}{l}\text { 22. Saya masih dilibatkan dalam kegiatan sosial di } \\
\text { lingkungan rumah }\end{array}$ & & & & \\
\hline 23. Saya masih aktif bergaul dengan tetangga. & & & & \\
\hline $\begin{array}{l}\text { 24. Saya masih aktif dalam kegiatan keagamaan } \\
\text { bersama di tempat ibadah saya }\end{array}$ & & & & \\
\hline $\begin{array}{l}\text { 25. Saya aktif menggunakan media sosial untuk } \\
\text { berkomunikasi dengan orang lain }\end{array}$ & & & & \\
\hline
\end{tabular}

